I tak współczesna medycyna opóźnia odejście, próbuje zawrócić chorego z podróży w zaświaty. Przydaje mu długie okresy w "życiu-nieżyciu”, kiedy umysł zamiera, a ciało toczy się od katastrofy do katastrofy. Myślę teraz o młodych ludziach, leczonych w zimie 2011 roku w naszym oddziale intensywnej terapii. To były najcięższe $\mathrm{w}$ Polsce południowej infekcje wirusem świńskiej grypy (A/H1N1). Widzieliśmy, jak u tej samej osoby raptownie spada poziom tlenu we krwi, serce zaczyna bić rytmem, nad którym nie mamy kontroli, płuca przestają oddychać i cała krew musi być przepompowywana tygodniami - tam i z powrotem - do oksygeneratora, stają nerki i konieczne są codzienne dializy, gorączka sięga czterdziestu jeden stopni, a z krwi wyrastają bakterie, krzepnięcie załamuje się i krew płynie z nosa, z ust, wylewa się na rozległych obszarach pod skórą. I kiedy po miesiącach zmagań pojawiały się pierwsze, nieśmiałe oznaki zdrowienia, chorzy zaczynali reagować, a potem mówić, aż wreszcie stawali na własnych nogach, budziło się w nas, oprócz radości przemożne zdumienie. Jeśli kiedyś widziałem duchy, to właśnie wtedy, duchy w ludzkim ciele.

A. Szczeklik, Nieśmiertelność, s. 70-71. 



\section{ETYCZNE KONSEKWENCJE ZANIKU ŚWIADOMOŚCI BYCIA ŚMIERTELNYM*}

\section{Wprowadzenie}

Nikt o zdrowych zmysłach nie będzie zaprzeczał, że człowiek jest istotą śmiertelną, a więc każdemu z nas przyjdzie kiedyś umrzeć. Niemniej jednak warto postawić pytanie, na jakiej podstawie człowiek sądzi, że kiedyś umrzeć musi. Przecieź śmierć jest zdarzeniem, które zawsze dotyczy innych ludzi, nigdy zaś nie dotyczy mnie; to innym zdarzyło się, że umarli, ja zaś ciągle żyję. W postawionym pytaniu nie chodzi o problem, który rozwiązał, jak mu się wydawało, grecki filozof Epikur (ok. 342-271 przed Chr.). Głosił on, że śmierć, która jest niczym innym, jak całkowitym pozbawieniem czucia, nie może dotyczyć człowieka, ponieważ gdy człowiek istnieje, śmierć jest nieobecna, a gdy śmierć się pojawi, człowieka już nie ma. Rozwiązanie podane przez Epikura nabiera sobie właściwego sensu w kontekście jego atomistycznej i sensualistycznej filozofii oraz ufundowanej na niej etyki racjonalnego hedonizmu'; celem jego zaś było uwolnienie ludzi od lęku przed śmiercią, jako że nie boimy się tego, co nas nie dotyczy.

* Niniejszy artykuł ukazał się pierwotnie w zbiorze: E. Krajewska-Kułak, W. Nyklewicz (red.), W drodze do brzegu życia, t. 1, Akademia Medyczna w Białymstoku, Wydział Pielęgniarstwa i Ochrony Zdrowia, Białystok 2006, s. 31-46. Faktycznie jest to zbiór materiałów pokonferencyjnych i jego dostępność jest dość ograniczona. Korzystając z okazji, przedstawiam wersję poprawioną i nieco zmodyfikowaną.

${ }^{1}$ Inną interpretację tezy Epikura, wolną od uwarunkowań jego filozofii, znaleźć można w: J. Kopania, Ludzkie oblicza boskiej Prawdy, Wydawnictwo Sokrates, Warszawa 1995, s. 59-79. 
Należy wyraźnie podkreślić, że postawiony powyżej problem nie jest problemem lęku przed śmiercią, lecz zagadnieniem empirycznych podstaw akceptacji tezy o ludzkiej śmiertelności. Jeżeli teza, że każdy człowiek kiedyś umrze, jest tezą prawdziwą, to do jej uznania nie dochodzimy drogą wnioskowania indukcyjnego. Wnioskowanie indukcyjne nie jest wnioskowaniem niezawodnym, czyli dopuszcza możliwość, że prawidłowo w sensie formalnym wyprowadzony wniosek może okazać się fałszywy; w tym wypadku znaczy to, że wnioskowanie indukcyjne mogłoby zostać sfalsyfikowane, gdyby zaistniał choć jeden człowiek żyjący wystarczająco długo, aby można było powątpiewać $\mathrm{w}$ jego śmiertelność. Zatem przekonanie o śmiertelności człowieka musi mieć jakąś inną podstawę.

\section{Hipoteza Maxa Schelera}

Pytanie o podstawę naszego przekonania co do śmiertelności natury ludzkiej postawił Max Scheler (1874-1928), fenomenolog twórczy głównie w dziedzinach etyki, antropologii filozoficznej i teorii wartości. Odpowiedź, której udzielił, miała wyjaśnić pewien fenomen przezeń zaobserwowany, a zarazem prowadzić ku szerszym rozważaniom dającym możność stworzenia swoistej filozofii śmierci. Podobnie jak w przypadku Epikura, również $\mathrm{u}$ Schelera jego stanowisko nabiera pełnego sensu dopiero $\mathrm{w}$ odniesieniu do jego fenomenologicznej postawy filozoficznej i koncepcji aksjologicznych. Jeśli jednak pominiemy tego rodzaju uwarunkowania i postawioną na początku XX wieku hipotezę Schelera przyjmiemy wyłącznie w jej teoriopoznawczym sensie, bez nakładania na nią interpretacji metafizycznych, wówczas może się ona stać wielce pomocna w zrozumieniu, jaką drogą podąża nasza cywilizacja u początku XXI stulecia.

Tym, co zaobserwował Scheler, był postępujący zanik wiary w życie pośmiertne, dokonujący się w kręgu cywilizacji zachodniej. Postawił więc pytanie, co jest przyczyną tej pogłębiającej się niewiary, i uznał, że umacnia się ona $\mathrm{w}$ miarę, jak zmienia się rozumienie, czy raczej pojmowanie, naszej śmiertelności.

Człowiek współczesny nie wierzy już w dalsze życie oraz w przezwyciężenie śmierci dzięki dalszemu życiu w tej mierze, w jakiej nie dostrzega już naocznie przed sobą własnej śmierci, w jakiej już nie „żyje w obliczu śmierci”, albo mówiąc ściślej: w jakiej stale obecny w naszej świadomości intuicyjny fakt, że śmierć jest dla nas czymś pewnym, wypiera z jasnej strefy swojej świadomości poprzez sposób życia i rodzaj zajęć, tak iż pozostaje jedynie wiedza w postaci sądu, że umrze. Jeśli sama śmierć nie 
jest jednak dana w tej bezpośredniej formie, jeśli jej nadchodzenie dane jest jedynie jako niekiedy pojawiająca się wiedza w postaci sądu, to również idea przezwyciężenia śmierci w dalszym życiu musi zblednać2.

Tak więc Scheler uznał, że dawniej człowiek był świadomy, że jest śmiertelny, obecnie natomiast jedynie wie, że kiedyś musi umrzeć. Ta zmiana jest, wedle niego, rzeczywistą przyczyną słabnięcia wiary w życie pozagrobowe.

Można mieć zastrzeżenia do zasadności toku rozumowania Maxa Schelera. Jego zdaniem zachodzi kolejność przyczynowo-skutkowa: najpierw dokonało się zastąpienie świadomości bycia śmiertelnym przez wiedzę na temat ludzkiej śmiertelności, a następnie jako tego zastąpienia konsekwencja następował stopniowy zanik wiary w nieśmiertelność duszy ludzkiej. Wydaje się jednak, że świadomość śmiertelności cielesnej i wiara w nieśmiertelność duchową pozostają względem siebie nie w zależności przyczynowo-skutkowej, lecz w relacji swoistego dopełniania się. Są dwiema stronami tego samego fenomenu, mianowicie wewnętrznej pewności co do natury człowieka jako bytu, który swym istnieniem wykracza poza sferę materialną.

Niemniej teza Schelera, że w miejsce dawnej świadomości bycia śmiertelnym człowiek ma obecnie jedynie wiedzę o swojej śmiertelności, może być traktowana jako swoista hipoteza myślowa, albowiem pozwala ona wyjaśnić zachodzące $w$ cywilizacji zachodniej pewne bardzo istotne zmiany w naszym pojmowaniu życia i śmierci. Sprowadzają się one do następujących: (1) zjawisko śmierci wypierane jest z obszaru intelektualnych i emocjonalnych działań ludzkich; (2) zanika dawne pojęcie świętości życia; (3) życie pojmowane jest obecnie jako wartość najwyższa; (4) wzmacniają się postawy roszczeniowe wobec medycyny.

\section{Ignorowanie śmierci}

Lęk przed śmiercią jest nieodłącznie związany z ludzkim życiem, albowiem i śmierć jest od życia biologicznego nieodłączna. Oczywiste więc, że człowiek poszukiwał sposobów umożliwiających mu zaakceptowanie zjawiska odczuwanego jako groźne i tajemnicze, a zarazem jako nieuniknione. Francuski historyk Philippe Ariès uzasadniał, że w europejskiej cywilizacji postawa wobec śmierci zmieniła się zasadniczo: od pierwotnej postawy pogodzenia się z faktem groźnym, lecz naturalnym, więc koniecz-

${ }^{2}$ M. Scheler, Śmierć i dalsze życie, [w:] tenże, Cierpienie, śmierć, dalsze życie. Pisma wybrane, przeł. A. Węgrzecki, Wydawnictwo Naukowe PWN, Warszawa 1994, s. 73-74. Wyróżnienia pochodzą od M. Schelera. 
nym, do postawy sprzeciwu wobec śmierci, wyrażającego się wypieraniem jej ze świadomości zarówno jednostkowej, jak i społecznej ${ }^{3}$. Pierwsza postawa realizuje wzorzec śmierci oswojonej, ujętej w społeczne rytuały umierania, pogrzebu i żałoby; druga postawa realizuje wzorzec śmierci zdziczałej, przemilczanej i ukrywanej, w szczególnym zaś przypadku - wzorzec śmierci opacznej, czyli umierania w szpitalu, wśród obcych ludzi, w stanie ubezwłasnowolnienia. Ariès sądzi, że ten drugi wzorzec stał się dominujący od początku XX wieku.

Zmiana postawy wobec śmierci jest faktem. I teza Schelera daje wyjaśnienie, w jaki sposób się dokonała. Jeżeli przyjmiemy, że człowiek miał kiedyś jakieś intuicyjne poznanie własnej śmiertelności, to natura tego poznania musiała być zbliżona do natury samoświadomości w sensie kartezjańskim. Świadomość samego siebie jest właściwa człowiekowi jako bytowi rozumnemu, warunkuje wszelkie inne jego działania świadome. Mówiąc po kartezjańsku, samoświadomość jednostki jest tożsama z jej istnieniem. Odkryte przez Descartes'a (1596-1650) myślenie, cogito, czyli samoświadomość, jest jedynym aktem podmiotu poznającego, który nie może być od tegoż podmiotu oddzielony ${ }^{4}$. Każdy jest świadomy samego siebie, czyli własnego istnienia, nie $\mathrm{w}$ tym sensie, jakoby stale czynił nad tym namysł, lecz w sensie niemożności zakwestionowania przez podmiot samego siebie w momencie, w którym podmiot czyni taki namysł. Moja świadomość samego siebie jest swoistym miejscem, w którym wszystko inne jawi mi się jako zewnętrzne wobec mnie i właśnie jako zewnętrzne jest przeze mnie uświadamiane sobie.

Świadomość własnej śmiertelności również byłaby więc oczywistością nie dającą się zakwestionować, rodzajem wewnętrznej pewności, której podmiot doświadcza w sposób analogiczny, jak doświadcza własnego istnienia. Tak jak nie da się zakwestionować własnego istnienia (albowiem ja wewnętrznie doświadczam, że istnieję), tak też nie da się zakwestionować własnej śmiertelności (albowiem ja wewnętrznie doświadczam, że istnieję docześnie). Podmiot jest świadomy własnej śmiertelności nie dlatego, że wszystko wokół niego przemija, lecz dlatego, że ma wewnętrzne przekonanie, iż zewnętrzna wobec niego rzeczywistość świata przestanie pozostawać wobec jego świadomości w tej relacji, w jakiej pozostaje aktualnie, ponieważ jego świadomość postawiona zostanie kiedyś w relacji do rzeczywistości transcendentnej względem rzeczywistości świata. Świadomość własnego istnienia i świadomość własnej śmiertelności stanowią więc zarazem egzystencjalne podłoże wiary w życie pośmiertne.

${ }^{3}$ Zob. Ph. Ariès, Człowiek i śmierć, przeł. E. Bąkowska, PIW, Warszawa 1989.

4 "Tak: to myślenie! Ono jedno nie daje się ode mnie oddzielić”; R. Descartes, Medytacje o pierwszej filozofii, t. 1, przeł. M. i K. Ajdukiewiczowie, Państwowe Wydawnictwo Naukowe, Warszawa 1958, s. 34. 
Jeżeli przyjmiemy założenie Maxa Schelera, iż tak rozumiana świadomość własnej śmiertelności uległa z jakichś powodów zanikowi ${ }^{5}$, zastąpiona została przez wiedzę o własnej śmiertelności, to konsekwentnie musimy przyjąć, że wewnętrzna oczywistość zastąpiona została zewnętrznym wobec świadomości podmiotu domniemaniem co do natury rzeczywistości - obserwowana przez podmiot w świecie zewnętrznym powszechna przemijalność odniesiona zostaje także do niego samego. Tak rozumiana wiedza o własnej śmiertelności nie może generować wiary w nieśmiertelność duchową po śmierci cielesnej. Przede wszystkim jednak owa wiedza o własnej śmiertelności, jak każda wiedza, może być wiedzą zapominaną. A zapominamy (staramy się zapominać) o tym, co jest dla nas niewygodne, przykre czy budzące lęk. Wiedza o śmiertelności jest wiedzą "niechcianą", ponieważ zmusza nas do myślenia o tym, o czym myśleć nie chcemy. Lepiej więc postarać się zapomnieć o tym, co tak bardzo przykre, i nie myśleć przynajmniej tak długo, jak na to pozwala stan organizmu. Współczesny człowiek zaczyna myśleć o śmierci dopiero wtedy, gdy już nie może o niej nie myśleć.

Hipoteza zaniku świadomości bycia śmiertelnym tłumaczy więc, dlaczego we współczesnej cywilizacji zachodniej dokonuje się proces wypierania zjawiska śmierci z obszaru emocjonalnych działań ludzkich. Śmierć jawi się jako zjawisko wyłącznie ze sfery biologicznej, nie zaś należące do sfery egzystencjalnej człowieka (nie mamy bowiem świadomości bycia śmiertelnymi); zarazem zaś jawi się jako zjawisko groźne i tragiczne (nie mamy bowiem wiary $\mathrm{w}$ nieśmiertelność). Jednocześnie zanik świadomości bycia śmiertelnym musiał spowodować zmiany w postawie człowieka wobec życia: świadomość bycia śmiertelnym związana jest $\mathrm{z}$ odczuwaniem życia $\mathrm{w}$ przestrzeni świętości, podczas gdy wiedza o śmiertelności związana jest $\mathrm{z}$ ocenianiem życia wedle kategorii jego jakości.

\section{Etyka świętości życia}

Świadomość, że jest się bytem śmiertelnym, musi determinować sposób odczuwania przez jednostkę własnego życia, jak też pojmowania życia w ogóle. Jeżeli bowiem świadomość śmiertelności jest rodzajem silnego wewnętrznego poczucia doczesności istnienia biologicznego, to również ży-

${ }^{5}$ Nie dyskutujemy tutaj, jakie to są powody. Max Scheler argumentuje, że były to dokonujące się od czasów nowożytnych zmiany w sposobie życia i w podejściu do życia, związane z rozwojem wiedzy naukowej i umiejętności technicznych. Warto byłoby zastanowić się, czy to tłumaczenie Schelera wpisuje się w tezę Stanisława Lema o destrukcyjnym wpływie nowoczesnych technologii na naszą cywilizację. Zdaniem Lema technologia jest zmienną niezależną naszej cywilizacji. O filozoficznych poglądach S. Lema zob. P. Okołowski, Materia i wartości. Neolukrecjanizm Stanistawa Lema, Wydawnictwa UW, Warszawa 2010. 
cie - owo doczesne istnienie biologiczne - musi jawić się w sposób szczególny: jako dane człowiekowi na pewien czas i po upływie tego czasu odbierane. Świadomość śmiertelności rodzi więc świadomość, silne wewnętrzne poczucie, że życie jest darem; że zostało dane człowiekowi jedynie „w użytkowanie", a nie do swobodnego nim dysponowania.

Świadomość bycia śmiertelnym jest więc warunkiem koniecznym ukształtowania się tej postawy wobec życia, którą zwykło się określać jako etykę świętości życia. Na zewnątrz przejawia się ona w kontekście religijnym: jako przekonanie, że życie jest darem Boga. W sferze działań międzyludzkich to, co darowane, staje się własnością obdarowanego, który może darem swobodnie dysponować. Zawsze jednak nakładano na obdarowanego określone wymagania dotyczące sposobu odwzajemnienia się; wymagania te tworzyły sieć relacji społecznych regulujących kontakty międzyludzkie ${ }^{6}$. Jest oczywiste, że dar pochodzący od Boga nie może być odwzajemniony w taki sposób, w jaki ludzie odwzajemniają dary między sobą. Dlatego wprawdzie świadomość bycia śmiertelnym rodzi przekonanie, że życie jest darem, ale zarazem rodzi przekonanie, że jest to dar, który trzeba będzie oddać wtedy i tylko wtedy, gdy sam Darczyńca tego zażąda. Życie jest święte, ponieważ zostało dane przez Boga; a jako święte nie może pozostawać w swobodnej dyspozycji człowieka.

„Upomnę się (...) u człowieka o życie człowieka i u każdego - o życie brata. [Jeśli - przyp. J.K.] kto przeleje krew ludzką, przez ludzi ma być przelana krew jego, bo człowiek został stworzony na obraz Boga"7. Te słowa Księgi Rodzaju wyrażają samą istotę rozumienia życia jako świętości. Jedynym dysponentem życia jest Bóg; jeśli więc człowiek odbierze drugiemu człowiekowi życie, tym samym staje się niegodny otrzymanego od Boga daru. Człowiek ma prawo odbierać życie drugiemu człowiekowi tylko w sytuacji zagrożenia własnego życia; a w pewnych szczególnych okolicznościach ma nawet obowiązek odebrania życia drugiemu człowiekowi: jako wykonanie kary za nieposzanowanie daru Boga. Etyka świętości życia nie dopuszcza zatem możliwości pozbawienia życia człowieka, który nie naruszył daru Boga, jak też samemu człowiekowi nie pozwala własnego życia naruszyć. Bezwzględnie zakazane są więc - jako czyny niemoralne - samobójstwo, eutanazja i aborcja. Każde życie ludzkie jest przy tym traktowane jednakowo - nie czyni się żadnych ocen ludzkiego życia z uwagi na jego stan, gdyż każde ma taką samą wartość ${ }^{8}$.

${ }^{6}$ Klasycznym omówieniem społecznej instytucji daru jest rozprawa: M. Mauss, Szkic o darze. Forma i podstawa wymiany w społeczeństwach archaicznych, [w:] tenże, Socjologia $i$ antropologia, Państwowe Wydawnictwo Naukowe, Warszawa 1973.

7 Rdz 9,5-6. Przekład Biblii Tysiąclecia.

${ }^{8}$ Należy zauważyć, iż w przeszłości teza o tej samej wartości każdego życia ludzkiego nie odnosiła się do wszystkich ludzi w sensie biologicznym. Niewolników nie uważano za ludzi, więc nie przysługiwała im żadna ochrona ich życia; dziecko stawało się człowiekiem dopiero 
Przekonanie, że życie to dar Boga, a zatem człowiek nie może nim dowolnie dysponować, jest obecne w cywilizacji chrześcijańskiej od samych jej początków, należy bowiem do natury religii chrześcijańskiej. Chrześcijaństwo było pod tym względem zgodne nie tylko z judaizmem, z którego przecież się wywodzi, lecz także z tą starożytną tradycją grecką, przede wszystkim platońską, która uzasadniała świętość życia jego boskim pochodzeniem9. Współczesne chrześcijaństwo także wyznaje zasadę świętości życia i jest to oczywiste, rezygnacja $\mathrm{z}$ tej zasady byłaby bowiem zaprzeczeniem jednej z najbardziej podstawowych tez chrześcijaństwa, mianowicie tezy o moralnych obowiązkach człowieka względem Boga-Stwórcy.

Każdy jest odpowiedzialny przed Bogiem za swoje życie, które od Niego otrzymał. Bóg pozostaje najwyższym Panem życia. Jesteśmy obowiązani przyjąć je z wdzięcznością i chronić je ze względu na Jego cześć i dla zbawienia naszych dusz. Jesteśmy zarządcami, a nie właścicielami życia, które Bóg nam powierzył. Nie rozporządzamy $\operatorname{nim}^{10}$.

Zacytowany artykuł Katechizmu Kościoła Katolickiego wyraża w sposób jednoznaczny teologiczne podstawy etyki świętości życia.

Znaczący jest jednak fakt, że chrześcijaństwo - w szczególności Kościoły katolicki i prawosławny ${ }^{11}$ - dostrzegają wyraźne zagrożenie zasady świętości życia w czasach obecnych. Zwiększająca się dechrystianizacja i sekularyzacja naszej cywilizacji powoduje odchodzenie od zasady świętości życia w takim stopniu, że Kościół katolicki wręcz widzi konieczność realizowania nowej ewangelizacji, aby przywrócić poszanowanie tradycyjnych wartości. Wyrazem tego rodzaju niepokojów stała się encyklika Jana Pawła II Evangelium vitae, ogłoszona w 1995 roku. Wskazując na wielorakie przejawy faktycznego odrzucania zasady świętości życia przez współczesną cywilizację zachodnią, papież podkreśla, że ustawodawstwo coraz większej liczby państw uznaje za całkowicie legalne te praktyki wymierzone przeciwko życiu, które jeszcze do niedawna uznawane były za niemoralne i przestępcze. Czyni przy tym znamienną uwagę:

z chwilą uznania go przez ojca, co tłumaczy dość powszechne w starożytności zjawisko dzieciobójstwa. Kwestia konsekwencji (czy raczej: niekonsekwencji) między uznawaniem tezy o świętości życia a praktykowaniem niewolnictwa czy dzieciobójstwa jest odrębnym zagadnieniem i wymaga osobnego potraktowania.

${ }^{9}$ Oczywiście nie tylko taka postawa była obecna w starożytnej myśli greckiej i rzymskiej; w szczególności inne poglądy w omawianej kwestii mieli stoicy. Szerzej na ten temat zob. J. Kopania, Boski sen o stworzeniu świata, Trans Humana, Białystok 2003, s. 95-119.

${ }^{10}$ Katechizm Kościoła Katolickiego, art. 2280, Pallottinum, Poznań 1994, s. 518.

11 Postawa kościołów protestanckich nie jest tak jednoznacznie związana z etyką świętości życia i w niektórych okolicznościach zbliża się do etyki jakości życia. Jest to konsekwencją zdominowania moralności protestanckiej przez etykę typu utylitarystycznego, a także etykę sytuacjonistyczną; zob. np. J. Fletcher, Situation Ethics: The New Morality, The Westminster Press, Philadelphia 1966. 
Nawet medycyna, która z tytułu swego powołania ma służyć obronie życia ludzkiego i opiece nad nim, w niektórych dziedzinach staje się coraz częściej narzędziem czynów wymierzonych przeciw człowiekowi i tym samym zniekształca swoje oblicze, zaprzecza samej sobie i uwłacza godności tych, którzy ją uprawiają ${ }^{12}$.

Rola medycyny może być, zdaniem papieża, szczególnie szkodliwa. Z jednej strony medycyna, o czym mowa w powyższym cytacie, coraz częściej dokonuje czynów, które z punktu widzenia etyki świętości życia muszą być uznane za akty skierowane przeciwko życiu. Z drugiej strony zaś medycyna dostarcza swoistego usprawiedliwienia dla działań wrogich życiu; polega to na tym, że głos sumienia przypominającego o świętości życia jest tłumiony poprzez odpowiednie stosowanie terminologii medycznej:

próbuje się przesłaniać niektóre przestępstwa przeciw życiu poczętemu lub zmierzającemu ku naturalnemu końcowi określeniami typu medycznego, które mają odwracać uwagę od tego, że w rzeczywistości zagrożone jest prawo konkretnego człowieka do istnienia"13.

Papieżowi chodzi oczywiście o perswazyjne użycie nazw medycznych; określenie „aborcja” może nie wzbudzać tak negatywnych skojarzeń jak określenie „zabicie dziecka poczętego”, a podobnie jest z określeniami „eutanazja” i „pozbawienie życia osoby nieuleczalnie chorej.

Wskazywany przez Jana Pawła II udział medycyny w procesie erozji etyki świętości życia jest jednak tylko oznaką zjawiska, nie zaś jego przyczyną. Życie przestaje być postrzegane w kategorii świętości z przyczyn zasadniczych, o charakterze metafizycznym, zatem jedynie zmiana owych przyczyn mogłaby spowodować powrót do odczuwania życia jako boskiego daru. Podjęcie wysiłku nowej ewangelizacji mogłoby być skuteczne tylko wówczas, gdyby ewangelizacja ta okazała się zdolna do przywrócenia człowiekowi utraconej świadomości bycia śmiertelnym. Nie przesądzając, czy jest to możliwe, należy jedynie skonstatować, że odchodzenie od etyki świętości życia nabiera przyspieszenia; ponieważ jedynie wiemy, że musimy kiedyś umrzeć, więc życie staje się dla nas coraz większą wartością - tym większą, im bardziej wypieramy z naszej świadomości wiedzę, że jesteśmy istotami śmiertelnymi.

\section{Etyka jakości życia}

Wiedza o własnej śmiertelności jest wiedzą „niechcianą”, ale to ona właśnie generuje odczuwanie życia w kategoriach wartości. Im bardziej boimy się śmierci, a więc im bardziej nie chcemy o niej myśleć, tym większą wartością staje się dla nas życie. Inaczej mówiąc, życie jawi się nam jako

12 Jan Paweł II, Evangelium vitae, p. 4, [w:] Encykliki Ojca Świętego Jana Pawła II, Znak, Kraków 1996, s. 845.

13 Tamże, p. 11, s. 855. 
wartość tym większa, im większy jest nasz lęk przed śmiercią. A życie jako wartość rozumiane jest zasadniczo inaczej niż życie jako świętość. Po pierwsze, życie jako wartość to pierwotnie i przede wszystkim wartość dla mnie, albowiem to życie jest moim życiem, jest dobrem, które posiadam; a skoro tak, to mogę nim swobodnie dysponować, podobnie jak dysponuję wszelkimi innymi stanowiącymi moją własność dobrami. Po drugie, wartość (jako wartość posiadanego dobra) jest wielkością zmienną, może wzrastać i maleć; a skoro tak, to wartość życia determinowana jest przez jego jakość. Wynika z tego logicznie, że gdy odpowiednio niski stopień jakości życia pozbawia to życie wartości, osoba dysponująca życiem może je zniszczyć. Na tej podstawie uznaje się dopuszczalność eutanazji, czyli rezygnacji z życia, które straciło wartość ${ }^{14}$, jak też dopuszczalność aborcji, czyli zniszczenia życia, które nie nabierze wystarczająco dużej wartości ${ }^{15}$. W tym kontekście także o wiele łatwiej wyraża się przyzwolenie na wszelkie działania mające polepszyć jakość życia, w szczególności działania z zakresu inżynierii genetycznej ${ }^{16}$. Jest pozornym tylko paradoksem, a w istocie logiczną konsekwencją tezy o życiu jako wartości najwyższej, że jej uznanie prowadzi do moralnego potępienia stosowania kary śmierci: życie ofiary już nie istnieje, nie jest więc istniejącą wartością, życie mordercy natomiast jest wartością istniejącą, a więc wartością najwyższą, czyli jego odebranie w ogóle nie może być rozważane jako kara $^{17}$.

Wiedza o śmiertelności jest więc warunkiem koniecznym ukształtowania się tej postawy wobec życia, którą zwykło się określać jako etykę jakości życia. Jest to etyka, w której życie stanowi wartość, ale nie jest świętością. Wydaje się, że etyka jakości życia zdobywa dominującą pozycję w cywilizacji zachodniej, do czego przyczyniają się - co brzmi paradoksalnie - sukcesy medycyny. Imponujące osiągnięcia medycyny umożliwiają utrzymywanie przy

14 Etyczne aspekty problemu omówione zostały w: J. Kopania, Eutanazja jako problem moralny w wymiarze jednostkowym i społecznym, "Wiadomości Lekarskie” 2002, LV, Suplement 1, cz. 1, s. 256-259. Na temat możliwych postaw wobec eutanazji zob. tenże, Trzy typy postaw wobec problemu eutanazji, „Sztuka Leczenia” 2002, nr 1, s. 59-68.

15 Interesujące w tym kontekście są dyskusje prawników i polityków nad polską ustawą o ochronie życia poczętego; zob. M. Nowacka, Polskie spory prawne o ksztatt ustawy antyaborcyjnej, "Archeus. Studia z Bioetyki i Antropologii Filozoficznej” 2003, nr 4, s. 17-33.

${ }^{16} \mathrm{~W}$ tej sferze działań jesteśmy dopiero u początku drogi, a najżywiej obecnie dyskutowaną kwestią jest moralna ocena klonowania. Zob. J. Kopania, Uwagi metodologiczne o etyczności klonowania człowieka, „Sztuka Leczenia” 2001, nr 1, s. 77-85; przedrukowane jako rozdział w: tenże, Etyczny wymiar cielesności, Wydawnictwo Aureus, Kraków 2002, s. 81-99.

17 Argumentację logiczną (neutralną światopoglądowo) za dopuszczalnością stosowania kary śmierci przedstawia B. Wolniewicz, Filozoficzne aspekty kary głównej oraz Jeszcze o karze głównej, [w:] tenże, Filozofia i wartości, t. 2, Wydział Filozofii Uniwersytetu Warszawskiego, Warszawa 1998, s. 206-232. Argumentację katolicką za dopuszczalnością kary śmierci przedstawia T. Ślipko, Kara śmierci z teologicznego i filozoficznego punktu widzenia, Wydawnictwo WAM, Kraków 2000. 
życiu osób, których stan organizmu dawniej prowadziłby do rychłego zgonu - problem polega na tym, że w bardzo wielu przypadkach jest to podtrzymywanie życia przepełnionego bólem, cierpieniem, także bez świadomości albo ze świadomością znacznie ograniczoną. Sytuacje takie skłaniają do postawienia pytania o sensowność podtrzymywania życia, którego jakość oceniana jest jako bardzo niska.

Widać oczywiście, że kategoria jakości nie jest tutaj kategorią etyczną, lecz kategorią psychologiczną względnie biologiczną. W konsekwencji jednak ocena moralna sytuacji nie jest i być nie może oceną dokonywaną na gruncie etyki deontologicznej, lecz może być dokonana jedynie na gruncie etyki utylitarystycznej. Etyka deontologiczna, czyli etyka powinności, dokonuje oceny moralnej ze względu na przyjęte normy moralne. Jeżeli więc dana etyka deontologiczna uznaje normę nakazującą bezwzględne poszanowanie życia, ponieważ życie jest świętością, to żadne celowe przerwanie życia niewinnej osoby nie może zyskać akceptacji moralnej. Etyka utylitarystyczna, czyli etyka użyteczności, ocenia natomiast czyn z punktu widzenia pożytku, jaki on przynosi, a mianowicie akceptuje te czyny, które zwiększają sumę dobra jednostkowego bądź społecznego. Jeżeli więc dana etyka utylitarystyczna uznaje życie za wartość, to w konkretnych sytuacjach może uznać, że jakość tej wartości jest tak niska, iż uzasadnia rezygnację z życia.

Najgłośniejszym utylitarystą propagującym etykę jakości życia jest australijski bioetyk Peter Singer ${ }^{18}$. Jego zdaniem rozwój nauk biomedycznych wykazał bez wątpienia, że tradycyjna etyka, czyli etyka świętości życia, jest niezdolna do oceny i tym bardziej rozwiązania szeregu problemów moralnych generowanych przez techniczne możliwości medycyny; co więcej, stosowanie kryteriów właściwych etyce tradycyjnej często prowadzi do tragedii. Nowa etyka odrzuca zatem właściwy starej etyce nakaz traktowania wszelkiego życia ludzkiego jako mającego taką samą wartość i zastępuje go nakazem uznania, iż wartość życia ludzkiego zmienia się. Wynikać z tego mają dalsze zmiany, $\mathrm{w}$ istocie sprowadzające się do uznania, że mamy moralny obowiązek dokonywania oceny (faktycznie oceny utylitarystycznej), co w danej sytuacji będzie większym dobrem: ratowanie życia czy zaniechanie ratowania, wstrzymanie się od działania czy aktywne przerwanie życia, donoszenie ciąży obciążonej ryzykiem czy dokonanie aborcji, wydanie na świat potomstwa czy powstrzymanie się od prokreacji, stawianie życia ludzkiego nad życie zwierzęce czy niewyróżnianie na podstawie przynależności gatunkowej. Singer jest przekonany, że chociaż jego poglądy i proponowane rozwiązania wzbudzają opory, to z czasem akceptacja tej nowej etyki będzie powszechna.

18 Zob. P. Singer, O życiu i śmierci. Upadek etyki tradycyjnej, przeł. A. Alichniewicz, A. Szczęsna, PIW, Warszawa 1997. 
Mimo wielkich kontrowersji jakie wywołuje nowa etyka - etyka jakości życia - Singer sądzi, że jest ona tak bardzo zasadna, a zarazem stanowi tak radykalny przełom, że należy ją uznać za „przewrót kopernikański” w etyce. „Nadszedł czas na nową rewolucję kopernikańską. I tym razem będzie to rewolucja przeciwko ideom otrzymanym w spadku po epoce, w której świat określała perspektywa religijna"19 - głosi australijski bioetyk. Nie przesądzając, czy etyka jakości życia rzeczywiście zastąpi etykę świętości życia, której to ewentualności odrzucić nie można, warto jednak wyrazić sceptycyzm co do zasadności porównywania jej znaczenia ze znaczeniem rewolucji kopernikańskiej. Jak słusznie zauważono ${ }^{20}$, wszystkie dotychczasowe "przewroty” $\mathrm{w}$ etyce polegały na tym, że nowa postawa moralna polegała na świadomym i celowym przeciwstawieniu się zastanej moralności ${ }^{21}$, czyli to nowa etyka zmieniała sposób postępowania ludzi, podczas gdy utwierdzanie się nowej etyki jakości życia polegać ma na takiej zmianie dotychczasowych zasad moralnych, aby stały się one zgodne z bieżącą praktyką, szczególnie praktyką medyczną, czyli to nowe sposoby postępowania ludzi zmieniać mają etykę.

\section{Postawy roszczeniowe wobec medycyny}

Bezpośrednią konsekwencją zastąpienia świadomości, że jest się śmiertelnym, wiedzą o śmiertelności, jest zapoczątkowanie tworzenia się etyki jakości życia. Konsekwencją pośrednią natomiast jest ważna zmiana w naszym stosunku do medycyny, mianowicie pojawienie się postaw roszczeniowych wobec praktyki medycznej. Oczywiście od samego początku człowiek oczekiwał od medycyny, że polepszy jego stan zdrowia lub odsunie moment śmierci. Jednak różnica polega na tym, że po raz pierwszy pojawiła się taka eskalacja żądań, która prowadzi do oskarżania medycyny, iż nie potrafi uczynić tego, co chcemy, aby czynić potrafiła. To, że medycyna w pewnych sytuacjach pozostaje bezradna, nie jest oceniane jako obiektywny fakt, którego przynajmniej na razie nie potrafimy zmienić, lecz jako grzech zaniedbania. Jeżeli bowiem życie jest największą wartością, to od dziedziny odpowiedzialnej za jego stan wymaga się szczególnie wiele.

Początki owego zwiększania odpowiedzialności nakładanej na medycynę związane są z dynamicznym rozwojem nauk przyrodniczych w czasach

19 Tamże, s. 207.

20 Zob. H. Promieńska, Rzeczywiste i pozorne "przewroty kopernikańskie” w etyce, czyli o bioetyce trochę dyskusyjnie, "Archeus. Studia z Bioetyki i Antropologii Filozoficznej” 2000, nr 1, s. 7-25.

21 Jako przykłady podać można sprzeciw moralny wobec instytucji niewolnictwa, głoszenie etyki miłości bliźniego, sprzeciw moralny wobec zasady nierówności stanowej, wobec stosowania tortur czy wprowadzenie przez Kanta pojęcia autonomii moralnej człowieka. 
nowożytnych. Szczególną rolę odegrała tu filozofia Descartes'a - ścisłe odseparowanie sfery materialnej od sfery duchowej z jednoczesnym uznaniem autonomiczności tej pierwszej, umożliwiło badanie przyrody wolne od ograniczeń metafizyki arystotelesowskiej, zmuszającej do poszukiwania ukrytych sił duchowych w bytach materialnych. Zamierzeniem Descartes'a było przyczynić się w jak największym stopniu do poznania zasad działania mechanizmu natury; filozof wierzył głęboko, że dzięki rozwojowi wiedzy możemy "stać się jak gdyby panami i posiadaczami przyrody" 22. Stopniowa i ciągła realizacja planu opanowania przyrody doprowadzać miała do ciągłego poszerzania zakresu umiejętności praktycznych.

Jest to nie tylko pożądane dla wynalezienia niezliczonego mnóstwa umiejętności, które by pozwoliły na korzystanie bez żadnego trudu z płodów ziemi i wszelkich dogodności, jakie się na niej znajdują, lecz przede wszystkim także dla zachowania zdrowia, które jest niewątpliwie naczelnym dobrem oraz podwaliną wszelkich innych dóbr tego życia; nawet umysł bowiem jest w tak wielkiej zależności od temperamentu i od układu narządów ciała, że jeśli tylko jest możliwe znalezienie jakiegokolwiek środka, który by uczynił ludzi na ogół mądrzejszymi i zręczniejszymi, niż byli dotychczas, mniemam, iż należy go szukać w medycynie ${ }^{23}$.

Zdrowie, to jest zdrowe życie, uznane zostało za największe dobro, a medycyna za najważniejszą z nauk, skoro to ona właśnie ma za zadanie troskę o stan naszego zdrowia. Zauważmy na marginesie: wprawdzie Kartezjusz nie mówi tego wprost, jednak jest w jego wypowiedzi ukryta myśl, że pogorszenie stanu zdrowia jest zarazem zmniejszeniem wartości tego dobra.

Medycyna współczesna jest spadkobierczynią kartezjańskiego mechanicyzmu przynajmniej w tym swoim wymiarze, $w$ jakim pozostaje leczeniem naprawczym. Oszałamiające postępy medycyny wraz z jednoczesnym umacnianiem się poczucia, iż życie jest wartością najwyższą, doprowadziły jednak do wytworzenia się wyraźnej prawidłowości: im więcej medycyna może, tym większe stawiamy wobec niej wymagania. Jest to zresztą zrozumiałe z psychologicznego punktu widzenia, ponieważ im większe są możliwości medycyny, tym większa rodzi się nadzieja, że i ten mój konkretny problem zdrowotny zostanie pozytywnie rozwiązany. Współczesny pacjent (a przecież każdy jest pacjentem albo aktualnym, albo potencjalnym) nie ma w swej relacji do lekarza poczucia pozostawania stroną zdominowaną, lecz w coraz większym stopniu chce decydować o trybie i procedurach leczenia. Jest to oczywiście rezultatem wzrastającego poczucia osobowej autonomiczności ludzi obecnych czasów, jednak problem autonomii pacjenta ${ }^{24}$ nie jest tylko

${ }^{22}$ R. Descartes, Rozprawa o metodzie, przeł. W. Wojciechowska, Państwowe Wydawnictwo Naukowe, Warszawa 1970, s. 72.

${ }^{23}$ Tamże, s. 72-73.

${ }^{24}$ Omówienie zagadnienia autonomii pacjenta z etycznego punktu widzenia znaleźć można w: M. Nowacka, Autonomia pacjenta jako problem moralny, Wydawnictwo Uniwersytetu w Białymstoku, Białystok 2005. 
problemem z zakresu etyki i antropologii filozoficznej. Autonomiczny w swej postawie i w swych działaniach człowiek jest przecież pozbawiony świadomości, że jest bytem śmiertelnym, a jedynie posiada wiedzę, że musi umrzeć, i ta wiedza go przeraża. Postawa autonomii wobec działań medycznych wyraża się więc także w postawie roszczeniowej wobec medycyny. Medycyna ma już nie tylko likwidować, na ile to możliwe, stany chorobowe i oddalać moment śmierci, lecz także powinna odsuwać tę śmierć w możliwie najdalszą przyszłość. Od tej postawy zaś jest już tylko jeden krok do nadziei, że kiedyś uda się medycynie odsunąć moment śmierci w nieskończoność. Pojawia się faktycznie żądanie, aby medycyna zapewniła nieśmiertelność, skoro nie ma już wiary w nieśmiertelność duchowąa

To żądanie od medycyny nieśmiertelności tu, na ziemi, nie może oczywiście znaleźć racjonalnego wyrazu - wiemy przecież, że jesteśmy śmiertelni, a więc wiemy, że śmierć jest wpisana w istotę życia biologicznego. Może zatem znaleźć jedynie wyraz pośredni, zakamuflowany: jako żądanie prawa do autonomii absolutnej, czyli przejawiającej się nie tylko w prawie do decydowania o formach i przebiegu terapii oraz w prawie do odmowy leczenia, ale także w prawie uzyskania od lekarza pomocy w umieraniu. Prawo to, czyli prawo do eutanazji, potrzebne jest po to, by człowiek mógł uprzedzić własną decyzją moment nadejścia śmierci; skoro bowiem medycyna jeszcze nie może odsunąć w nieskończoność tego momentu, to niech przynajmniej da człowiekowi poczucie władzy nad własnym życiem. Prawo odmowy leczenia zaś jest wprawdzie niezbywalnym prawem człowieka, wynikającym z jego osobowej natury, jednak w niektórych przypadkach skrajnych zasadniczo zmienia swój charakter - staje się wyrażeniem nieufności wobec medycyny, która nie gwarantuje wyzdrowienia. Taka jest rzeczywista przyczyna rezygnacji z terapii medycznej na rzecz rozmaitych zabiegów „medycyny alternatywnej” czy działań „paramedycznych”. Człowiek ma prawo zamiast tomografii komputerowej wybrać wahadełko, a zamiast chemioterapii przyjmować "bioprądy" od "bioenergoterapeuty”. Autonomia osoby ludzkiej stanowi podstawę tego prawa. Tyle że $w$ takich wypadkach realizacja tego prawa jest $w$ swej istocie infantylną zemstą, którą ciężko chory człowiek wywiera na medycynie za

${ }^{25}$ Nadzieję, że rozwój wiedzy i technologii zapewni w niedalekiej już przyszłości uwolnienie ludzkiej świadomości od nośnika cielesnego, a tym samym zapewni nieśmiertelność jednostkowej jaźni, głoszą tzw. transhumaniści. Zob. N. Bostrom, A history of transhumanist thought, "Journal of Evolution and Technology" 2005, nr 14, s. 1. Bogusław Wolniewicz ocenia, że „są to mrzonki metafizyczne. Przypuśćmy bowiem, że w wyniku jakichś gigantycznych transformacji ewolucyjnych - gdyby np., jak suponuje Stanisław Lem, ewolucja miała przesunąć się za sprawą człowieka ze związków węgla na związki krzemu - powstaną jakieś istoty rozumne nie naznaczone jak my piętnem Adama. To nie będą to już ludzie (...), a ich istnienie jest nam równie obojętne, jak nasze obojętne jest np. szczurom"; B. Wolniewicz, O istocie religii, [w:] tenże, Filozofia i wartości, t. 1, dz. cyt., s. 198. 
to, że nie może ona mu pomóc w sposób niezawodny. Człowiek nie ma już bowiem świadomości, że jest bytem śmiertelnym; wie zaś, że musi umrzeć, i bardzo tego nie chce.

\section{Uwagi końcowe}

Fenomen śmierci, a także problem stosunku człowieka do tego fenomenu, są zagadnieniami wyjątkowo trudnymi zarówno w swym aspekcie filozoficznym, jak i na płaszczyźnie psychologicznej. Istnieje zresztą olbrzymia literatura na ten temat, jak też wykształciła się odrębna dziedzina wiedzy bioetycznej, mianowicie tanatologia, rozważająca różnorodne zagadnienia związane $\mathrm{z}$ namysłem nad śmiercią we wszelkich jej odmianach, jakie mogą dotyczyć człowieka ${ }^{26}$. Samo powstanie bioetyki jako odrębnej dziedziny etyki normatywnej jest wyrazem narastania problemów generowanych przez intensywny rozwój nauk biomedycznych ${ }^{27}$, choć trzeba też odnotować obecność postaw negujących zasadność wyodrębniania bioetyki jako jednej z etyk szczegółowych ${ }^{28}$. Tego rodzaju głosy krytyczne zasługują na baczną uwagę i gruntowny namysł, u ich podłoża leży bowiem podejrzenie, iż rzeczywistym zadaniem bioetyki jest wypracowywanie takich sposobów usprawiedliwiania kolejnych eksperymentów biomedycznych, aby społeczeństwa stopniowo, w sposób dla siebie niezauważalny, akceptowały je. W kontekście powyższych rozważań należy szczególną uwagę zwrócić na zmianę, która dokonała się w kwestii medycznego kryterium śmierci; jest to zmiana znacząca z moralnego punktu widzenia, rodzi bowiem niejasność co do faktycznych motywów leżących u jej podstaw: czy chodziło (jak się oficjalnie twierdzi) jedynie o podanie bardziej precyzyjnego kryterium uznania pacjenta za zmarłego, czy jednak chodzi o utylitarnie pojętą korzyść medyczną²9.

${ }^{26}$ Obszernym kompendium tak pojętej tanatologii (jako dziedziny bioetyki, czyli jednej z etyk normatywnych) jest monografia: M. Adamkiewicz, Zagadnienie śmierci w bioetyce, Wydawnictwo Wojskowej Akademii Technicznej, Warszawa 2002.

27 Zwięzłym, ale bardzo ilustratywnym przedstawieniem głównych problemów bioetycznych z perspektywy etyki życia jest: D. Ślęczek-Czakon, Problem wartości i jakości życia w sporach bioetycznych, Wydawnictwo Uniwersytetu Śląskiego, Katowice 2004.

${ }_{28}$ Zob. B. Wolniewicz, O tzw. bioetyce, [w:] tenże, Filozofia i wartości, t. 3, Wydział Filozofii Uniwersytetu Warszawskiego, Warszawa 2003, s. 149-164.

29 Przywoływany już kilkakrotnie B. Wolniewicz nie wątpi, że motywacja była pragmatyczna i utylitarna: chodziło o szybszy dostęp do materiału transplantacyjnego; zob. szereg artykułów tego autora poświęconych moralnej (negatywnej) ocenie chirurgii transplantacyjnej, zamieszczonych w cytowanym trzytomowym zbiorze Filozofia $i$ wartości. O rozróżnieniu między śmiercią organizmu a śmiercią człowieka zob. J. Kopania, M. Nowacka, Śmierć organizmu a śmierć człowieka, „Sztuka Leczenia” 1999, nr 4, s. 51-60. O utylitarystycznych wyznacznikach medycznego rozumienia śmierci zob. M. Nowacka, Ku utylitarystycznej definicji śmierci, [w:] 
Fascynujące odkrycia nauk biomedycznych, w szczególności genetyki, oraz zwiększające się możliwości techniczne ingerowania w organizm ludzki wyraźnie wskazują, że jesteśmy na początku drogi prowadzącej do zasadniczego przełomu w naszym rozumieniu życia, a w konsekwencji także $\mathrm{w}$ naszym rozumieniu człowieka jako istoty biologicznej i jako istoty przekraczającej uwarunkowania biologiczne. Przy założeniu, że nasza cywilizacja - jedyna cywilizacja zarazem scjentystyczna i personalistyczna - będzie nadal istnieć i rozwijać się, musimy dojść do wniosku, że w niedalekiej przyszłości ludzkość stanie wobec wyzwań moralnych nieporównywalnych z dotychczasowymi. Możemy zasadnie domniemywać, że człowiek przyszłości będzie $\mathrm{w}$ jakimś sensie innym człowiekiem niż człowiek obecny, a w takim razie również jego moralność będzie moralnością nową, od tradycyjnej odmienną i z nią nieporównywalną. Nie możemy przy tym stawiać pytania, czy będzie to moralność lepsza; takie pytanie byłoby nieprawomocne metodologicznie, ponieważ to już nie będzie nasza, lecz ich moralność. Możemy natomiast uznać (z metafizycznego punktu widzenia), że początkiem owej drogi do nowej moralności stało się utracenie świadomości bycia śmiertelnym i zastąpienie jej wiedzą o naszej śmiertelności.

\section{Ethical consequences of the loss of the consciousness of being mortal}

Sum mary

Max Scheler argued that the consciousness of being mortal was replaced by the knowledge of being mortal in the modern period, so now human beings only know that they are mortal. The goal of the article is to prove that this replacement has great ethical consequences, i.e. it is mainly the cause of the dominance of utilitarian ethics in Western civilization.

H. Promieńska (red.), Etyka wobec problemów wspótczesnego świata, Wydawnictwo Uniwersytetu Śląskiego, Katowice 2003, s. 156-164. Metodologiczną charakterystykę obowiązującej obecnie definicji śmierci mózgowej znaleźć można w: J. Kopania, Metodologiczna charakterystyka definicji śmierci mózgowej, „Archeus. Studia z Bioetyki i Antropologii Filozoficznej” 2000, nr 1, s. 163-172 (wersja angielska: Methodological Description of Brain Death Definition, „Studies in Logic, Grammar and Rhetoric" 2003, nr 6, s. 101-106); przedrukowane jako rozdział w: tenże, Etyczny wymiar cielesności, dz. cyt., s. 70-80. 
